\title{
Vitamin D Status in Pregnancy: Fetomaternal Outcome and Correlation with Cord Blood Vitamin D
}

\author{
${ }^{1}$ Mamta Gupta, ${ }^{2}$ Arijit Debnath, ${ }^{3}$ Sanjay Jain, ${ }^{4}$ Vandana Saini, ${ }^{5}$ Somosri Ray
}

\begin{abstract}
Introduction: Hypovitaminosis $D$ in pregnancy has been reported to cause various maternal effects, i.e., hypocalcemia, subclinical myopathy, increased risk of preeclampsia (PE), gestational diabetes mellitus (GDM), cesarean sections, and fetal effects, i.e., neonatal tetany, hyperbilirubinemia congenital rickets, infantile rickets, etc. Only few Indian studies are available in this regard.

Objective: To estimate serum vitamin $D$ levels in pregnant women, cord blood, and study fetomaternal outcomes.

Materials and methods: A prospective observational study was conducted on 54 consecutive pregnant women and their newborn babies. Serum 25-hydroxy vitamin D [25(OH)D] level was estimated in all women at the time of admission in labor ward. They were followed up to delivery and 48 hours postpartum. Vitamin $\mathrm{D}$ was also estimated in cord blood collected during delivery. All results were recorded and analyzed statistically.
\end{abstract}

Results: The mean $25(\mathrm{OH}) \mathrm{D}$ level in pregnancy was $6.81 \pm 7.38$ $\mathrm{ng} / \mathrm{mL}$. The mean $25(\mathrm{OH}) \mathrm{D}$ level in their babies (cord blood) was $6.34 \pm 7.05 \mathrm{ng} / \mathrm{mL}$. There was very strong positive correlation between maternal and fetal serum $25(\mathrm{OH}) \mathrm{D}$ levels ( $p$-value 0.001 , r-value 0.9 ). Vitamin $D$ deficiency was strongly associated with obesity, PE, and GDM ( $p$-value 0.001). Neonatal jaundice and tetany were also significantly associated with severe vitamin $\mathrm{D}$ deficiency.

Conclusion: Low levels of vitamin $D$ have been observed in pregnant women and their newborn babies. Hypovitaminosis $D$ has been associated with adverse fetomaternal outcomes. As there is a strong correlation of maternal and neonatal levels, supplementing vitamin $\mathrm{D}$ in a pregnant women might improve these adverse pregnancy outcomes.

Keywords: Cord blood vitamin D, Fetomaternal outcome, Hypovitaminosis D, Vitamin D status in pregnancy.

\footnotetext{
${ }^{1}$ Senior Consultant and Head, ${ }^{2}$ Resident Medical Officer cum Clinical Tutor, ${ }^{3,4}$ Senior Specialist, ${ }^{5}$ Assistant Professor

1,4 Department of Obstetrics and Gynecology, Hindu Rao Hospital and North Delhi Municipal Corporation Medical College, New Delhi, India

${ }^{2}$ Department of Obstetrics and Gynecology, College of Medicine \& J.N.M. Hospital, Kalyani, West Bengal, India

${ }^{3}$ Department of Pathology, Hindu Rao Hospital and North Delhi Municipal Corporation Medical College, New Delhi, India

${ }^{5}$ Department of Pediatrics, Kolkata Medical College, Kolkata West Bengal, India

Corresponding Author: Mamta Gupta, Senior Consultant and Head, Department of Obstetrics and Gynecology, Hindu Rao Hospital and North Delhi Municipal Corporation Medical College, New Delhi, India, Phone: +919868611385, e-mail: write2mamta55@gmail.com
}

How to cite this article: Gupta M, Debnath A, Jain S, Saini V, Ray S. Vitamin D Status in Pregnancy: Fetomaternal Outcome and Correlation with Cord Blood Vitamin D. Indian J Med Biochem 2017;21(1):42-48.

Source of support: Nil

Conflict of interest: None

\section{INTRODUCTION}

India being a tropical country, it is thought that vitamin $\mathrm{D}$ deficiency would not be common. Despite abundant sunshine, vitamin D deficiency has been recognized to be highly prevalent in India as reported from studies done in Delhi $\left(28.3^{\circ} \mathrm{N}\right){ }^{1}$ Lucknow $\left(26.8^{\circ} \mathrm{N}\right)^{2}$ and Tirupathi $\left(13.4^{\circ} \mathrm{N}\right) .{ }^{1}$ The high prevalence of vitamin D insufficiency during pregnancy is increasingly recognized, especially in dark women, following customs like veil, in women living in northern latitudes and during winter season. ${ }^{1,3,4}$ Maternal effects of hypovitaminosis $\mathrm{D}$ have been reported to cause calcium malabsorption, bone loss, poor weight gain, subclinical myopathy, ${ }^{5}$ increased preeclampsia (PE), increased gestational diabetes mellitus (GDM) ${ }^{7}$ increased cesarean sections. ${ }^{8}$ In the newborn, hypovitaminosis D has been reported to cause neonatal tetany, ${ }^{9}$ hyperbilirubinemia, ${ }^{10}$ large fontanelle, enamel defects, congenital rickets, and infantile rickets. ${ }^{11}$ There is growing evidence that hypovitaminosis D can also have long-lasting effects on health of the offspring, i.e., impaired skeletal growth and rickets. ${ }^{5,11}$ In a community-based study of 901 mother and offspring pairs, researchers found that maternal vitamin D deficiency (serum 25-hydroxyvitamin $\mathrm{D}[25(\mathrm{OH}) \mathrm{D}]<50 \mathrm{nmol} / \mathrm{L})$ at 18 weeks pregnancy was associated with impaired lung development at age 6 in offspring, neurocognitive difficulties at age 10, increased risk of eating disorders in adolescence, and lower peak bone mass at 20 years of age. ${ }^{12}$ Very few Indian studies have been done regarding vitamin D status during pregnancy, so it was considered worthwhile to study vitamin D status in pregnancy, its fetomaternal effects, and its correlation with cord blood levels.

\section{AIMS AND OBJECTIVES}

To estimate total serum vitamin $\mathrm{D}$, i.e. $25(\mathrm{OH}) \mathrm{D}_{2}+25(\mathrm{OH})$ $\mathrm{D}_{3}$ levels in pregnancy and find out its association with fetomaternal outcome and cord blood 25(OH)D levels. 


\section{MATERIALS AND METHODS}

This study was a prospective observational study conducted in the Department of Obstetrics and Gynecology at a tertiary hospital in Delhi, India, from March 2012 to February 2013. Approval from Institutional Ethical Committee was obtained. After informed written consent, 70 pregnant women with singleton pregnancy attending antenatal clinic in third trimester were enrolled in consecutive order and followed up till 48 hours of delivery.

Pregnant women having known liver disorders, kidney disorders, history of antitubercular and antiepileptic drugs, pregestational diabetes, and chronic hypertension were excluded from the study. Women taking vitamin D supplements were excluded from the study. All women were counseled for diet with good nutritive value as per routine for all pregnant women, including leafy vegetables, milk, curd, eggs, cheese, pulses, fruits. As a routine for antenatal women, they were advised to take ferrous sulfate $100 \mathrm{mg}$ and calcium $500 \mathrm{mg}$ tablets twice a day. Demographic data, detailed history, physical examination, and obstetric examination were recorded.

All women were subjected to routine antenatal investigations and other relevant investigations if required. Screening for GDM was done by estimating blood glucose levels 2 hours after 75 gm glucose intake in all women at 24 to 28 weeks. A value $\geq 140 \mathrm{mg} \%$ was taken as diagnosis of GDM. ${ }^{13}$ Any complication occurring during antenatal period was recorded. Serum calcium and serum vitamin $\mathrm{D}$ were estimated during admission to labor ward. Vitamin D was estimated by chemiluminescence method. All the women were followed up till delivery and 48 hours postpartum. After delivery, cord was cut and blood sample was collected from the maternal end of cord for estimation of 25(OH)D.

Fetal outcome parameters like birth weight and crown heel length were recorded. Head circumference and fontanelle size were measured after 24 hours of birth. Baby was observed for development of any neonatal jaundice, tetany, or seizure. All the observations were recorded on a predesigned proforma and analyzed.

\section{ESTIMATION OF VITAMIN D}

Vitamin D was estimated in all women using CLIA Cobas e 411 (Roche) in the Pathology Department. The most reliable marker of vitamin $\mathrm{D}$ status is its metabolite, $25(\mathrm{OH})$ $\mathrm{D}$, which has a half-life of 3 weeks, is biologically inactive with levels approximately 1,000 times greater than its active metabolite, i.e., $1,25(\mathrm{OH}) \mathrm{D}$.

The assay employs a vitamin $\mathrm{D}$ binding protein (VDBP) as a capture protein in the assay which binds to $25(\mathrm{OH}) \mathrm{D}$. Addition of microparticles and hydroxy vitamin D labeled with biotin causes the free sites of VDBP to become occupied. The microparticles are magnetically captured on an electrode which induces chemiluminescent emission measured by a photomultiplier. Vitamin D insufficiency was considered as levels $<20 \mathrm{ng} / \mathrm{mL}$ in our study.

\section{Statistical Analysis}

Categorical variables were expressed as number of patients, percentages and compared across the groups using Pearson's chi-square test for independence of attributes. Continuous variables were expressed as mean \pm standard deviation and compared across the groups using unpaired t-test and analysis of variance test where applicable. Statistical Package for the Social Sciences software version 16 was used for analysis. An alpha level of 0.05 was considered significant.

\section{RESULTS}

Out of 70 subjects recruited fulfilling inclusion criteria, 54 subjects could be followed up for delivery and up to 48 hours postpartum.

The mean age of women in our study was $23.89 \pm 3.2$ years. Most of the women belonged to the age group 21 to 25 years. The mean body mass index (BMI) of women was $24.32 \pm 4.09$. Majority of women were Hindu by religion. Except for BMI the demographic distribution of women in terms of age, religion, and season was comparable in relation to vitamin $\mathrm{D}$ (Table 1).

The baseline investigations, i.e., mean hemoglobin, total leukocyte count (TLC), platelet counts, and serum calcium, were in the normal reference range. Mean vitamin D level was found to be low $(6.81 \pm 7.38 \mathrm{ng} / \mathrm{dL})$ in our study (Table 2).

Basic parameters in terms of BMI, TLC, and serum calcium were found to be statistically significant in various subgroups of vitamin D levels. Preeclampsia and GDM were also found to be significantly more (p-values 0.023 and 0.039 respectively) in women with lower vitamin D level subgroup (Table 3).

Fetomaternal outcome and mean vitamin D was also evaluated. It was seen that mean vitamin $\mathrm{D}$ was significantly higher (p-value 0.001 ) in women who were normotensive and normoglycemic compared with those having PE and GDM. Vitamin D was found to be comparable in terms of onset of labor i.e. spontaneous or induced labor and mode of delivery i.e. vaginal or cesarean delivery. Birth weight and neonatal biometry also did not have any significant difference in terms of mean vitamin D levels. Vitamin D was significantly higher (p-value 0.001) in women whose babies did not 
Table 1: Demographic distribution and vitamin D levels

\begin{tabular}{llll}
\hline Parameter & $n$ & Mean vitamin D (ng/mL) & $p$-value \\
\hline Age & & \\
Mean (years) & $23.89 \pm 3.2$ & $6.81 \pm 7.38$ \\
$\quad<20$ & $9(16.7 \%)$ & $5.52 \pm 6.63$ & $5.80 \pm .66$ \\
$21-25$ & $31(57.4 \%)$ & $9.09 \pm 1.82$ & $14.63 \pm 10.65$ \\
$26-30$ & $2(22.2 \%)$ & \\
$\quad>30$ & $20(3.7 \%)$ & \\
BMI, kg/m & & $8.98 \pm 8.92$ \\
Mean & $24.32 \pm 4.09$ & $7.43 \pm 0.53$ \\
$\quad 18.5 \leq 25$ & $32(59.3 \%)$ & $3.29 \pm 1.01$ \\
$\quad 25 \leq 30$ & $2(3.7 \%)$ & \\
$\quad>30$ & $20(37.0 \%)$ & $6.70 \pm 7.20$ \\
Religion & & $8.28 \pm 10.56$ \\
Hindu & $50(92.6 \%)$ & \\
Muslim & $4(7.4 \%)$ & $5.78 \pm 4.53$ \\
Women recruited in (n) & & $7.47 \pm 8.73$ \\
Summer (March to October) & $21(38.9 \%)$ & 0.417 \\
Winter (November to February) & $33(61.1 \%)$ & 0.684 \\
\hline
\end{tabular}

Table 2: Baseline lab investigations

\begin{tabular}{llc}
\hline Parameter & Mean values & Reference ranges \\
\hline Hemoglobin, gm\% & $10.45 \pm 0.81$ & $\geq 11$ in pregnancy \\
& & $9-10.9$ mild anemia in pregnancy \\
TLC $($ per cmm) & $10,100 \pm 2,123.08$ & $5,000-12,000$ \\
Platelets $($ per cmm) & $240,000 \pm 52,160.8$ & $149,000-429,000$ \\
Serum calcium, $\mathrm{mg} / \mathrm{dL}$ & $9.58 \pm 0.74$ & $8.2-9.7$ \\
Serum vitamin D, $\mathrm{ng} / \mathrm{mL}$ & $6.81 \pm 7.38$ & $>20$ optimum levels \\
& & $<20$ hypovitaminosis \\
\hline
\end{tabular}

Table 3: Maternal variables according to severity of hypovitaminosis $D$

\begin{tabular}{|c|c|c|c|c|c|c|}
\hline \multirow[b]{2}{*}{ Maternal variables } & \multicolumn{4}{|c|}{ Vitamin $D$ levels in mother } & \multicolumn{2}{|l|}{ Total } \\
\hline & $\begin{array}{l}<5 n g / m L \\
n=35(\%)\end{array}$ & $\begin{array}{l}5-10 \mathrm{ng} / \mathrm{mL} \\
n=10(\%)\end{array}$ & $\begin{array}{l}10-20 \mathrm{ng} / \mathrm{mL} \\
n=5(\%)\end{array}$ & $\begin{array}{l}>20 n g / m L \\
n=4(\%)\end{array}$ & $n=54,100 \%$ & $p$-value \\
\hline $\mathrm{BMI}\left(\mathrm{kg} / \mathrm{m}^{2}\right) 18.8 \leq 25$ & $16(29.6 \%)$ & $7(13 \%)$ & $5(9.6 \%)$ & $4(7.4 \%)$ & $32(59.3 \%)$ & 0.002 \\
\hline $25 \leq 30$ & $0(0 \%)$ & $2(3.7 \%)$ & $0(0 \%)$ & $0(0 \%)$ & $2(3.7 \%)$ & \\
\hline$\geq 30$ & $19(35.1 \%)$ & $1(1.9 \%)$ & $0(0 \%)$ & $0(0 \%)$ & $20(37.0 \%)$ & \\
\hline Season - Summer & $14(26 \%)$ & $4(7.4 \%)$ & $3(5.6 \%)$ & $0(0 \%)$ & $21(38.9 \%)$ & 0.320 \\
\hline Winter & $21(38.9 \%)$ & $6(11.1 \%)$ & $2(3.7 \%)$ & $4(7.4 \%)$ & $33(61.1 \%)$ & \\
\hline $\mathrm{Hb} \%(\mathrm{gm} / \mathrm{dL})$ mean & $10.4 \pm 0.86$ & $10.43 \pm 0.61$ & $10.46 \pm 0.69$ & $10.95 \pm 0.98$ & 54 & 0.649 \\
\hline TLC (per cmm) mean & $109,00 \pm 1,718.6$ & $9,530 \pm 1,765.75$ & $8,100 \pm 1,044$ & $6,375 \pm 838.15$ & 54 & 0.001 \\
\hline Platelets mean (per $\mathrm{cmm}$ ) & $\begin{array}{l}245,000 \pm \\
46,402.19\end{array}$ & $\begin{array}{l}222,000 \pm \\
42,450.1\end{array}$ & $\begin{array}{l}224,000 \pm \\
61,175.98\end{array}$ & $\begin{array}{l}258,000 \pm \\
105,050.78\end{array}$ & 54 & 0.493 \\
\hline Serum calcium mean $(\mathrm{mg} / \mathrm{dL})$ & $9.35 \pm 0.66$ & $9.68 \pm 0.59$ & $10.2 \pm 0.39$ & $10.55 \pm 0.9$ & 54 & 0.001 \\
\hline Pregnancy outcome - PE & 16 & 1 & 0 & 0 & 17 & \\
\hline Normotensive & 19 & 9 & 5 & 4 & 37 & 0.023 \\
\hline GDM present & 18 & 3 & 0 & 0 & 21 & \\
\hline GDM absent & 17 & 7 & 5 & 4 & 33 & 0.039 \\
\hline
\end{tabular}

have jaundice and tetany than those having neonatal jaundice and tetany (Table 4).

A strong positive correlation was found between maternal serum vitamin $\mathrm{D}$ and cord blood vitamin $\mathrm{D}$ (p-value 0.001, r-value 0.9; Table 5 and Graph 1).

\section{DISCUSSION}

The mean age in our study was $23.89 \pm 3.2$ years (Table 1 ) similar to Marwaha et $\mathrm{al}^{1}$ and Sachan et $\mathrm{al}^{2}$ in pregnant women. Age had no association with mean vitamin D levels (p-value 0.239; Table 1). 
Vitamin D Status in Pregnancy: Fetomaternal Outcome and Correlation with Cord Blood Vitamin D

Table 4: Fetomaternal outcome and mean maternal vitamin $D$ levels

\begin{tabular}{|c|c|c|c|}
\hline Outcome & $n=54(\%)$ & Mean vitamin $D$ & $p$-value \\
\hline PE present & $17(31.5 \%)$ & $3.31 \pm 0.99$ & 0.001 \\
\hline PE absent & $37(68.5 \%)$ & $8.43 \pm 8.44$ & \\
\hline GDM present $(n=21)$ & $21(38.9 \%)$ & $3.69 \pm 1.67$ & 0.001 \\
\hline GDM absent $(n=33)$ & $33(61.1 \%)$ & $8.80 \pm 8.83$ & \\
\hline Onset of labor - spontaneous & $36(66.7 \%)$ & $7.01 \pm 6.48$ & 0.786 \\
\hline Induction done & $18(33.3 \%)$ & $6.42 \pm 9.11$ & \\
\hline Mode of delivery - vaginal & $41(75.9 \%)$ & $7.32 \pm 7.72$ & 0.326 \\
\hline LSCS & $13(24.1 \%)$ & $4.85 \pm 5.75$ & \\
\hline Birth weight $-<2,500 \mathrm{gm}$ & $3(5.6 \%)$ & $3.00 \pm 0$ & 0.362 \\
\hline$>2,500 \mathrm{gm}$ & $51(94.4 \%)$ & $7.04 \pm 7.533$ & \\
\hline Apgar score at 1 minute $-4-6$ & $1(1.9 \%)$ & 3 & - \\
\hline $7-10$ & $53(98.1 \%)$ & $6.84 \pm 7.45$ & \\
\hline Neonatal tetany - present & $7(13 \%)$ & $3.0 \pm 0$ & 0.001 \\
\hline Absent & $47(87 \%)$ & $7.339 \pm 7.786$ & \\
\hline Neonatal jaundice - present & $35(64.8 \%)$ & $5.81 \pm 5.38$ & 0.001 \\
\hline Absent & $19(35.2 \%)$ & $8.656 \pm 9.998$ & \\
\hline Crown heel length $-<47 \mathrm{~cm}$ & $3(5.5 \%)$ & $4.8 \pm 3.12$ & 0.305 \\
\hline $47-50 \mathrm{~cm}$ & $44(81.5 \%)$ & $7.54 \pm 7.97$ & \\
\hline$>50 \mathrm{~cm}$ & $7(13 \%)$ & $3.11 \pm 0.3$ & \\
\hline Head circumference $-<34 \mathrm{~cm}$ & $14(25.9 \%)$ & $4.7 \pm 2.35$ & 0.282 \\
\hline $34-36 \mathrm{~cm}$ & $40(74.1 \%)$ & $7.46 \pm 8.4$ & \\
\hline Fontanelle size - normal & $50(92.6 \%)$ & $7.1 \pm 7.6$ & 0.313 \\
\hline more than normal & $4(7.4 \%)$ & $3.2 \pm 0.4$ & \\
\hline
\end{tabular}

Table 5: Serum vitamin D in maternal and cord blood

\begin{tabular}{lllll}
\hline $\begin{array}{l}\text { Vitamin D levels } \\
(n g / m L)\end{array}$ & $\begin{array}{l}\text { Mother } \\
(n) \%\end{array}$ & $\begin{array}{l}\text { Cord blood } \\
(n) \%\end{array}$ & p-value $r$-value \\
\hline $\begin{array}{l}\text { Vitamin D levels } \\
<5 \text { (severe deficiency) }\end{array}$ & $35(64.8 \%)$ & $40(74.1 \%)$ & 0.001 & 0.9 \\
$5-10$ (deficiency) & $10(18.5 \%)$ & $04(7 \%)$ & & \\
$10-20$ (insufficiency) & $05(9 \%)$ & $07(13 \%)$ & \\
$>20$ (optimum) & $04(7.4 \%)$ & $03(5.5 \%)$ & \\
Mean vitamin D & $6.81 \pm 7.38$ & $6.34 \pm 7.05$ & \\
\hline
\end{tabular}

In our study, $92.6 \%$ of pregnant women were found to be having hypovitaminosis $\mathrm{D}$ (serum vitamin $\mathrm{D}$ $<20 \mathrm{ng} / \mathrm{mL}$ ). A high prevalence of vitamin D deficiency has been revealed in various other studies. Sachan et $\mathrm{al}^{2}$ reported $84.3 \%$ urban and $83.6 \%$ rural women with vitamin D deficiency in a study in northern India. Study in second trimester of pregnancy by Sahu et $\mathrm{al}^{14}$ has shown a prevalence of vitamin D deficiency to be $74.1 \%$. Hypovitaminosis D has been reported to be $70.7 \%$ in southern part of India ${ }^{15}$ and $93.5 \%$ in northern India. ${ }^{16}$ Dasgupta et $a l^{17}$ showed $56 \%$ of prevalence from northeastern part of India. A predominant nonvegetarian food habit might be the cause for lower percentage of hypovitaminosis D. Despite abundant sunshine in our country, the high prevalence of vitamin D deficiency might be due to darker skin with melanin preventing the entry of ultraviolet (UV) rays in the skin, people remaining indoors mainly, use of sunscreens, malabsorption, less

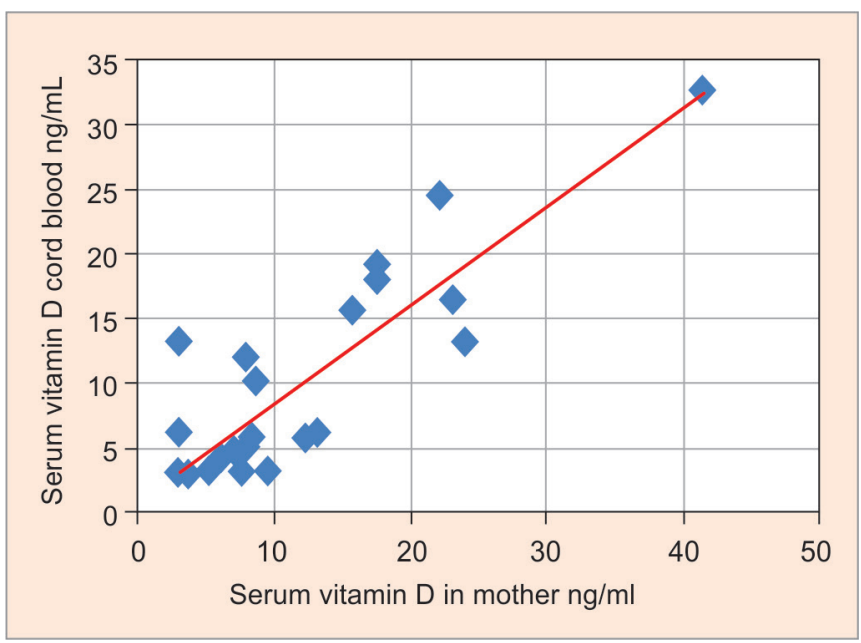

Graph 1: Scatter diagram showing maternal and cord blood vitamin $D$ correlation. $p$-value $=0.001, r$-value $=0.9$

exposure to sunshine, a vegetarian diet, less intake of calcium in the form of milk and other dairy products being expensive, nonfortified foods, and milk.

Vitamin D insufficiency was seen in $9 \%$ (serum vitamin D 10-20 ng $/ \mathrm{mL}$ ) of women and 19\% were found to be deficient (serum vitamin D 5-<10 $\mathrm{ng} / \mathrm{mL}$ ). Severe deficiency (serum vitamin $\mathrm{D}<5 \mathrm{ng} / \mathrm{mL}$ ) was seen in $65 \%$ women. Only $7 \%$ women had optimal levels of vitamin $\mathrm{D}$ in our study.

In our study, the mean maternal serum 25(OH)D level was $6.81 \pm 7.38 \mathrm{ng} / \mathrm{mL}$ (Table 2). A value of $14 \pm 9.5 \mathrm{ng} /$ 
$\mathrm{mL}$ was reported by Sachan et al. ${ }^{2}$ Harinarayan et $\mathrm{al}^{18}$ have reported mean vitamin D level of $15.5 \pm 0.3 \mathrm{ng} / \mathrm{mL}$ in urban women and $19 \pm 0.89 \mathrm{ng} / \mathrm{mL}$ in rural women. The lower mean maternal vitamin $\mathrm{D}$ level might be due to urban lifestyle of the women remaining mainly indoors, more number of obese women, and increased pollution preventing skin to exposure of UV rays.

In our study, no significant difference (p-value 0.684 ) in vitamin D levels in women recruited in summer (March to October) and winter (November to February) was found, though several studies showed higher prevalence of maternal vitamin D deficiency when delivered during winter and spring. Zhuang et $\mathrm{al}^{19}$ have reported lowest vitamin D level in spring, with $25(\mathrm{OH}) \mathrm{D}$ concentration $<50 \mathrm{nmol} / \mathrm{L}$ in $98.6 \%$ of mothers and $99.3 \%$ of their neonates.

Obesity is a risk factor for vitamin D deficiency. There were 20 pregnant women with BMI > 30 in our study, $95 \%$ $(n=19)$ of them had severe vitamin D deficiency which was statistically significant (p-value 0.002 ; Table 3 ). This may be explained based on the sequestration of $25(\mathrm{OH})$ $D$ in adipose tissue in obese women. Similar observations were made by Wortsman et al. ${ }^{20}$

Vitamin D also appears to play a role in reducing inflammation. Those with adequate levels of vitamin D in their blood were less likely to develop inflammation. An inverse relation between 25(OH)D below its median and $C$-reactive protein (CRP) was found to be significant (geometric mean CRP change $0.11 \mathrm{mg} / \mathrm{dL}$ for each $10 \mathrm{ng} / \mathrm{mL}$ change in $25(\mathrm{OH}) \mathrm{D}) .{ }^{21}$ A significant difference in leukocyte count was observed in vitamin D-deficient women in our study (p-value 0.001; Table 2). Excess $1,25(\mathrm{OH}) 2 \mathrm{D}$ is produced in an effort to upregulate the vitamin D receptor (VDR) to express antimicrobial peptides, such as cathelicidin and beta defensins which attack pathogens, and $25(\mathrm{OH}) \mathrm{D}$ is rapidly metabolized in the process, resulting in a low serum level. ${ }^{22}$

Several studies highlighted that maternal vitamin $\mathrm{D}$ deficiency was an independent risk factor for PE as reported by Bodnar et al. ${ }^{6}$ The active form of vitamin $\mathrm{D}$, $1,25(\mathrm{OH}) 2 \mathrm{D}_{3}$, has been shown to regulate the transcription and function of genes associated with placental invasion, normal implantation, and angiogenesis ${ }^{23}$ supported by the known stimulatory effects of calcitriol on the expression of vascular endothelial growth factor in vascular smooth muscle cells through vitamin $D$ response elements in the vascular endothelial growth factor promoter. ${ }^{24}$ It is also believed to be important in directing immune responses by dendritic cells and macrophages at the fetal/placental interface as well as immunological adaptation by the mother to reduce the risk of infection and inflammation. ${ }^{23}$
In our study, there were significantly more ( $\mathrm{p}$-value $0.023)$ number of women who developed PE $(n=16)$ in the severe deficiency group. No women had PE with vitamin D sufficiency group (vitamin D $>20 \mathrm{ng} / \mathrm{mL}$; Table 3). The mean vitamin $\mathrm{D}$ levels in women who developed PE were $3.31 \pm 0.99 \mathrm{ng} / \mathrm{mL}$, which was significantly low (p-value 0.001 ) compared with mean vitamin $\mathrm{D}(8.43 \pm 8.44 \mathrm{ng} / \mathrm{mL})$ in women who did not develop PE (Table 4). Extrapolating this observation, it can be said that supplementing vitamin $\mathrm{D}$ can reduce risk of PE in pregnant women and can help in reducing PE-related fetomaternal morbidity and mortality.

Vitamin D enhances expression of insulin gene, resulting in high insulin synthesis. ${ }^{25}$ It also influences insulin secretion by regulating intracellular calcium levels ${ }^{26}$ in insulin-sensitive tissues, such as muscle and adipose tissues. Vitamin D also improves insulin resistance by upregulating the insulin receptors. ${ }^{27}$ As hypovitaminosis $\mathrm{D}$ by promoting inflammatory response induces insulin resistance, vitamin D by its modulating effect on the immune system ${ }^{28}$ enhances insulin response. The difference in mean vitamin D level in GDM and non-GDM group $(3.69 \pm 1.67$ and $8.80 \pm 8.83 \mathrm{ng} / \mathrm{mL}$ respectively) was found to be statistically significant (p-value $<0.001$ ) in our study (Table 4). In women who developed GDM $(n=21), 85.7 \%(n=18)$ belonged to the severe deficiency group (Table 3). Therefore, supplementing vitamin D might reduce risk of GDM in pregnant women and its associated adverse fetomaternal outcomes.

Women with cesarean deliveries had lower mean vitamin D compared with those having vaginal deliveries, though the difference was not significant in our study. Vitamin D was lower with spontaneous onset of labor compared with induction. There was no association between low vitamin $\mathrm{D}$ level and need of induction of labor (p-value 0.786 ) or mode of delivery in our study (p-value 0.326; Table 4). Merewood et $\mathrm{al}^{29}$ have reported cesarean section to be four times more common in women with vitamin D levels $<37.5 \mathrm{nmol} / \mathrm{L}$. Scholl et $\mathrm{al}^{8}$ have found an association between vitamin D deficiency and cesarean section for prolonged labor. Poor maternal vitamin D status is associated with poor muscle tone of pelvic floor and reduced pelvic muscle strength, reducing ability to push.

Khalessi et $\mathrm{al}^{30}$ found a significant difference in birth weight of babies of mothers who had higher vitamin D levels. Vitamin D has a key role in fetal growth by its interaction with parathyroid hormone and $\mathrm{Ca}^{2+}$ homeostasis. Mannion et $\mathrm{al}^{31}$ have shown that each additional cup of milk daily was associated with a $41 \mathrm{gm}$ increase in birth weight $(95 \%$ confidence interval 
14.0-75.1 gm); each additional microgram of vitamin D, with an 11 gm increase (95\% confidence interval 1.2-20.7 gm). Mothers with suboptimal vitamin D status have offspring with reduced intrauterine and postnatal skeletal development. In our study, mothers with babies having birth weight $>2,500 \mathrm{gm}$ had a higher mean vitamin D level $(7.04 \pm 7.533 \mathrm{ng} / \mathrm{mL})$ compared with mothers whose babies had birth weight $<2,500 \mathrm{gm}$, though the difference was not statistically significant ( $p$-value 0.362 ). The vitamin $\mathrm{D}$ nuclear receptor polymorphism, $V d r$ Fok (FF/FF), is an effect modifier of birth weight with $8 \%$ lower birth weight in maternal vitamin D deficiency $(<11.2 \mathrm{ng} / \mathrm{mL}) .^{32}$ Pawley and Bishop ${ }^{33}$ found a significant association between umbilical cord $25(\mathrm{OH}) \mathrm{D}$ concentrations and head circumference at 3 and 6 months postnatal age. Maghbooli et $\mathrm{al}^{34}$ found significantly wider posterior fontanelle diameter in neonates of mothers with vitamin D deficiency (as defined by a $25(\mathrm{OH})$ D level $<34.9 \mathrm{nmol} / \mathrm{L}$ or $\sim 14 \mathrm{ng} / \mathrm{mL}$ ) compared with neonates whose mothers were not deficient. However, no significant difference in crown heel length, head circumference, and anterior fontanelle size was seen in relation to mean vitamin D levels (p-value $0.305,0.282$, 0.313 respectively) in our study. Adequate nutritional vitamin $\mathrm{D}$ status during pregnancy is important for fetal skeletal development, bone mineralization, tooth enamel formation, and perhaps general fetal growth.

It was observed in our study that neonatal tetany was strongly associated with maternal severe vitamin $\mathrm{D}$ deficiency ( $p$-value 0.001; Table 4), similar to the study by Delvin et al. ${ }^{35}$

We found a strong association between severe vitamin Ddeficiency and neonatal jaundice ( $p$-value $<0.001$; Table 3) similar to that reported by Mutlu et al. ${ }^{10}$ Although bilirubin and vitamin $\mathrm{D}$ metabolisms are two distinct pathways and are very different, at least one part of the synthesis takes place in a common organ, the liver. Therefore, the metabolism or synthesis of one may affect the other. ${ }^{10}$

The mean cord blood vitamin D was $6.34 \pm 7.05 \mathrm{ng} / \mathrm{mL}$. Deficiency of vitamin D (levels $<10 \mathrm{ng} / \mathrm{mL}$ ) was seen in $81.5 \%(n=44)$ of babies and $83.3 \%(n=45)$ of mothers. There was an excellent positive correlation between maternal and cord blood vitamin D levels (p-value 0.001, r-value 0.9; Table 5, Graph 1). This suggests that vitamin D status in the mother is reflected in vitamin D status in the baby. Jacquemyn et $\mathrm{al}^{36}$ have reported high correlation between overall prenatal and cord blood levels ( $r$-value $0.91)$. A significant $(r=0.6 ; p<0.001)$ correlation between maternal and cord blood vitamin D levels was observed by Kumar et $\mathrm{al}^{15}$ and Sachan et $\mathrm{al}^{2}(\mathrm{r}=0.79)$. Therefore, supplementation of vitamin $\mathrm{D}$ in the mother may reduce the adverse fetal outcome and might help to improve the long-term ill-effects of hypovitaminosis D in the baby.

\section{LIMITATIONS}

Though this is definitely a venture to look into this important aspect from Indian perspective, there is need of larger randomized trials to prove the causal association between maternal vitamin D deficiency with fetomaternal outcome. The authors have also not included in their study the interventional arm to see the beneficial effects, if any, by vitamin D supplementation on fetomaternal outcome.

\section{CONCLUSION}

Prevalence of vitamin D is quite high in the population catered by our institute. Body mass index was associated with deficiency of vitamin D. Increased white blood cell and decreased serum calcium level were found to be statistically significant in women with vitamin D deficiency. Occurrence of PE and GDM was significantly more in women with hypovitaminosis D. A significantly more neonatal jaundice and tetany was seen in babies of mothers having hypovitaminosis $\mathrm{D}$. There was an excellent correlation between maternal and fetal (cord blood) vitamin D status. Strategy to improve maternal status of vitamin D might help to improve neonatal status also, thereby helping to reduce the various adverse fetomaternal outcomes seen with hypovitaminosis D.

\section{REFERENCES}

1. Marwaha RK, Tandon N, Reddy DR, Aggarwal R, Singh R, Sawhney RC, Saluja B, Ganie MA, Singh S. Vitamin D and bone mineral density status of healthy schoolchildren in northern India. Am J Clin Nutr 2005 Aug;82(2):477-482.

2. Sachan A, Gupta R, Das V, Aggarwal A, Awasthi PK, Bhatia V. High prevalence of vitamin D deficiency among pregnant women and their newborns in northern India. Am J Clin Nutr 2005 May;81(5):1060-1064.

3. Choi R, Kim S, Yoo H, Cho YY, Kim SW, Chung JH, Oh SY, Lee SY. High prevalence of vitamin D deficiency in pregnant Korean women: the first trimester and the winter season as risk factors for vitamin D deficiency. Nutrients 2015 May 11;7(5):3427-3448.

4. Lips P, Van SN, de Jongh RT. Diet, sun, and lifestyle as determinants of vitamin D status. Ann N Y Acad Sci 2014 May;1317: 92-98.

5. Holick MF. Resurrection of vitamin D deficiency and rickets. J Clin Invest 2006 Aug;116(8):2062-2072.

6. Bodnar LM, Catov JM, Simhan HN, Holick MF, Powers RW, Roberts JM. Maternal vitamin D deficiency increases the risk of preeclampsia. J Clin Endocrinol Metab 2007 Sep;92(9): 3517-3522.

7. Maestro B, Dávila N, Carranza MC, Calle C. Identification of a vitamin $\mathrm{D}$ response element in the human insulin receptor gene promoter. J Steroid Biochem Mol Biol 2003 Feb;84 (2-3):223-230. 
8. Scholl TO, Chen X, Stein P. Maternal vitamin D status and delivery by caesarean. Nutrients 2012 Apr;4(4):319-330.

9. Thomas TC, Joshua MS, White PC, Adhikari S. Transient neonatal hypocalcemia: presentations and outcomes. Paediatrics 2012;129(6):1461-1467.

10. Mutlu M, Cayir A, Cayir Y, Ozkan B, Aslan Y. Vitamin D and hyperbilirubinemia in neonates. HK J Paediatr (new ser) 2013;18:77s-81s.

11. Weisberg P, Scanlon KS, Li R, Cogswell ME. Nutritional rickets among children in the United States: review of cases reported between 1986 and 2003. Am J Clin Nutr 2004 Dec;80 (Suppl 6):1697S-1705S.

12. Tangpricha V, Khazai NB. Vitamin D deficiency and related disorders. Medscape 2016 Oct.

13. Sesiah V, Das AK, Balaji V, Joshi SR, Parikh MN, Gupta S, Diabetes in Pregnancy Study Group. Gestational diabetes mellitus - guidelines. J Assoc Physicians India 2006 Aug;54: 622-628.

14. Sahu M, Bhatia V, Aggarwal A, Rawat V, Saxena P, Pandey A, Das V. Vitamin D deficiency in rural girls and pregnant women despite abundant sunshine in northern India. Clin Endocrinol 2009 May;70(5):680-684.

15. Kumar P, Shenoi A, Kumar RK, Girish SV, Subbaiah S. Vitamin $\mathrm{D}$ deficiency among women in labor and cord blood of new borns. Indian Pediatr 2015 Jun;52(6):530-531

16. Sharma S, Kumar A, Prasad S, Sharma S. Current scenario of vitamin D status during pregnancy in North India population. J Obstet Gynecol India 2016 Apr;66(2):93-100.

17. Dasgupta A, Saikia UK, Sarma D. Status of 25(OH)D level in pregnancy: a study from North-eastern part of India. Indian J Endocrinol Metab 2012 Dec;16 (Suppl 2):S405-S407.

18. Harinarayan CV, Ramalakshmi T, Prasad UV, Sudhakar D, Srinivasarao PV, Sarma KV, Kumar EG. High prevalence of low dietary calcium, high phytate consumption and vitamin D deficiency in healthy south Indians. Am J Clin Nutr 2007 Apr;85(4):1062-1067.

19. Zhuang XL, Zhu ZW, Zhu DB, Chen LQ, Zhao ZY, Shao J. Maternal-neonatal vitamin D status and related factors. Zhonghua Er Ke Za Zhi 2012 Jul;50(7):498-503.

20. Wortsman J, Matsuoka LY, Chen TC, Lu Z, Holick MF. Decreased bioavailability of vitamin D in obesity. Am J Clin Nutr 2000 Sep;72(3):690-693.

21. Amer M, Qayyum R. Relation between serum 25-hydroxyvitamin D and C-reactive protein in asymptomatic adults (from the continuous National Health and Nutrition Examination Survey 2001 to 2006). Am J Cardiol 2012 Jan 15;109(2):226-230.

22. Mangin $M$, Sinha R, Fincher K. Inflammation and vitamin $D$ : the infection connection. Inflamm Res 2014 Oct;63(10):803-819.
23. Evans KN, Bulmer JN, Kilby MD, Hewison M. Vitamin D and placental decidual function. J Soc Gynecol Investig 2004 Jul;11(5):263-271.

24. Cardus A, Panizo S, Encinas M, Dolcet X, Gallego C, Aldea M, Fernandez E, Valdivielso JM. 1,25-dihydroxyvitamin D3 regulates VEGF production through a vitamin D response element in the VEGF promoter. Atherosclerosis 2009 May;204(1): 85-89.

25. Maestro B, Molero S, Bajo S, Dávila N, Calle C. Transcriptional activation of the human insulin receptor gene by 1,25 dihydroxyvitamin $\mathrm{D}_{3}$. Cell Biochem Funct 2002;20(3):227-232.

26. Pittas AG, Lau J, Hu FB, Dawson-Hughes B. The role of vitamin $D$ and calcium in type 2 diabetes: a systematic review and meta-analysis. J Clin Endocrinol Metab 2007 Jun;92(6): 2017-2029.

27. Palomer X, Gonzalez-Clemente JM, Blanco-Vaca F, Mauricio D. Role of vitamin $\mathrm{D}$ in the pathogenesis of type 2 diabetes mellitus. Diabetes Obes Metab 2008 Mar;10(3):185-197.

28. Aranow C. Vitamin D and the immune system. J Investig Med 2011 Aug;59(6):881-886

29. Merewood A, Mehta SD, Chen TC, Bauchner H, Holick MF Association between vitamin D deficiency and primary cesarean section. J Clin Endocrinol Metab 2009 Mar;94(3): 940-945.

30. Khalessi N, Kalani M, Araghi M, Farahani Z. The relationship between maternal vitamin $D$ deficiency and low birth weight neonates. J Family Reprod Health 2015 Sep;9(3):113-117.

31. Mannion CA, Gray-Donald K, Koski KG. Association of low intake of milk and vitamin D during pregnancy with decreased birth weight. CMAJ 2006 Apr 25;174(9):1273-1277.

32. Morley R, Carlin JB, Pasco JA, Wark JD, Ponsonby AL. Maternal 25-hydroxyvitamin $\mathrm{D}$ concentration and offspring birth size: effect modification by infant VDR genotype. Eur J Clin Nutr 2009 Jun;63(6):802-804.

33. Pawley N, Bishop NJ. Prenatal and infant predictors of bone health: the influence of vitamin D. Am J Clin Nutr 2004 Dec;80(6):1748S-1751S

34. Maghbooli Z,Hossein-Nezhad A,Shafaei A,Karimi F, Madani F, Larijani B. Vitamin D status in mothers and their newborns in Iran. BMC Pregnancy Childbirth 2007 Feb 12;7:1.

35. Delvin EE, Salle BL, Glorieux FH, Adelein P, David LS. Vitamin D supplementation during pregnancy: effect on neonatal calcium homeostasis. J Pediatr 1986 Aug;109(2): 328-334.

36. Jacquemyn Y, Ajaji M, Karepouan N. Vitamin D levels in maternal serum and umbilical cord blood in a multi-ethnic population in Antwerp, Belgium. Facts Views Vis Obgyn 2013;5(1):3-5. 